\title{
FORMAT HUKUM ISLAM DI INDONESIA
}

\author{
Muhammad Aiz \\ STIT Al Marhalah AI 'Ulya Bekasi \\ Jl.KH Mas Mansur 91 Bekasi Jaya Timur, Kota Bekasi 17112 \\ Email: muammadaiz@gmail.com
}

\begin{abstract}
The Form of Islamic Law in Indonesia. This studies supports the opinion of Ibn al-Muqaffa (756 AD) which states the need for unification of the rules that applicable to all citizens, including regulations derived from the Qur'an and Hadith. In addition, Muhammad Abduh (1849-1905) stated that the teachings of Islam applied by the previous scholars do not apply eternally, and become a contemporary contemporary obligation to formulate the law in accordance with the demands of time and environment. This article contradicts the opinion of Muhammad Ibn Abdul Wahab (1703-1792 AD) which defines the law based only on textual literature without giving place to the understanding of majazi and qiyasi laws. In addition, Taqiyuddin al-Nabhani (19091977) which states the need to establish the khilafah for the enforcement of Islamic law throughout the country. The methodology used in this paper is descriptive qualitative research using the approach of law sciences.
\end{abstract}

Keywords: Islamic Law, Reconception, Unification

Abstrak: Format Hukum Islam di Indonesia. Artikel ini mendukung pendapat Ibn al-Muqaffa (756 M) yang menyatakan perlu adanya unifikasi peraturan yang berlaku bagi semua warga negara,termasuk peraturan yang bersumber dari Alquran dan Hadis. Selain itu juga Muhammad Abduh (1849-1905) menyatakan bahwa ajaran Islam yang diterapkan ulama terdahulu tidak berlaku abadi, dan menjadi kewajiban di masa kontemporer saat ini untuk memformulasikan hukum sesuai dengan tuntutan masa dan lingkungan. Artikel ini menentang pendapat Muhammad Ibn Abdul Wahab (1703-1792 M) yang mengartikan hukum hanya berdasarkan literatur (tekstual) tanpa memberi tempat pada pemahaman hukum secara majazi dan qiyasi. Selain itu, Taqiyuddin al-Nabhani (1909-1977)yang menyatakan perlunya mendirikan Khilafah guna ditegakannya syariat Islam di seluruh negeri. Metodologi yang dipergunakan dalam tulisan ini adalah penelitian kualitatif deskriptif dengan menggunakan pendekatan ilmu hukum.

Kata Kunci: Hukum Islam, Rekonsepsi, Unifikasi 


\section{Pendahuluan}

Hukum Islam saat ini merupakan salah satu sistem hukum yang dipergunakan di dunia, yang pada prakteknya masih banyak disalahpahami oleh dunia barat. ${ }^{1}$ Menurut sumbernya, maka Hukum Islam itu berasal dari 4 sumber, yaitu (1) Alquran; (2) Sunnah; (3)Ijma; dan (4) Qiyas. Secara mendasar masih adanya pemahaman yang keliru terkait dengan keberadaan Hukum Islam yang hidup dan berkembang sebagai sebuah sistem hukum di berbagai negara. Ketidakpahaman akan adanya perbedaan antara dua istilah yaitu "syari' ah" dan "fiqih" menjadikan kerancuan di tengah masyarakat. ${ }^{2}$

Alquran sebagai sumber utama Hukum Islam merupakan kalam Tuhan yang menjadi pedoman utama. Namun pemahaman akan Alquran itu sendiri dalam bentuk kitab-kitab tafsir berjumlah sangat banyak, sehingga pada akhirnya masyarakat memiliki pemahaman yang beragam. Setidaknya ada sekitar 350-500 ayat yang terkait dengan persoalan hukum. ${ }^{3}$ Sumber utama yang kedua dalam Hukum Islam adalah Sunnah, yang merupakan pelengkap dari Alquran yang terus menerus muncul selama nabi Muhammad SAW hidup. ${ }^{4}$ Sumber kedua ini pun tidak lepas dari adanya multi penafsiran terkait dengan derajat kesahihan hadis menurut kelompok Sunni maupun Syi'ah yang cenderung dipengaruhi oleh berbagai persoalan di luar hadis itu sendiri, seperti politik dan lainnya, yang pada akhirnya akan berpengaruh terhadap perumusan Hukum Islam. Melihat kenyataan adanya perbedaan pemahaman dari kedua sumber utama tersebut, maka akan menjadi suatu keniscayaan manakala adanya perbedaan konsep dalam Hukum Islam di berbagai tempat.

\footnotetext{
${ }^{1}$ Mashood Baderin, Understanding Islamic Law in Theory and Practice, Legal Information Management,9, 2009, h.186.

${ }^{2}$ H. Abd Al-Ati, The Family Structure in Islam (Indianapolis: ATP, 1977) h.,14

${ }_{3}$ T.Mahmood, Law in the Qur'an: A Draft Code, Islamic Comparative Law , Quarterly 1, $1987,7$.

${ }^{4}$ S. Ramadan, Islamic Law: Its Scope and Equity (London: Macmillan,1970),h.16
} 


\section{Diskursus Format Hukum Islam di Negara Indonesia}

Format Hukum Islam yang menjadi diskursus panjang sejak Indonesia merdeka akan terus mengalami perdebatan seiring dengan perkembangan zaman. Format Hukum Islam yang mengutamakan diberlakukannya syariat Islam secara "kaffah" dalam perkembangannya saat ini masih terus muncul. Salah satu tokohnya adalah Syekh Taqiyuddin al-Nabhani, yang juga pendiri Hizbut Tahrir, yang mengemukakan gagasan untuk didirikannya Khilafah (Dawlah Isla>miyyah) guna diberlakukannya syariat Islam di seluruh dunia termasuk Indonesia. Penegakan syariat Islam tersebut tidak hanya sebatas dalam hal muamalah saja namun juga dalam kaitannya dengan pidana bahkan politik ${ }^{5}$. Persoalan jihad juga termasuk kewenangan yang dimiliki oleh pemimpin khilafah tersebut untuk memberikan persetujuan atas aksi tersebut. ${ }^{6}$ Gerakan yang berawal dari negeri Palestina ini di masa reformasi Indonesia telah muncul dan berkembang pesat.

Usulan format Hukum Islam sebagaimana diusung oleh sekelompok masyarakat Indonesia yang tergabung dalam Hizbut Tahrir Indonesia (HTI) sesungguhnya merupakan realitas hukum yang saat ini hidup di Indonesia. Kelompok lain yang hampir memiliki tujuan yang sama antara lain ialah Majelis Mujahidin Indonesia (MMI),Front Pembela Islam (FPI), Laskar Jihad, dan Jamaah Anshorut Tauhid (JAT)7. Oleh karenanya format Hukum Islam yang mereka tawarkan dapat menjadi bahasan yang sangat penting dalam memformat ulang Hukum Islam di Indonesia ini.

Pandangan dari kelompok yang menginginkan direalisasikannya Hukum Islam sesuai dengan apa yang tercantum dalam Alquran dan Hadis sesungguhnya tidak dapat dilepaskan dari pandangan Ibn Taymiyyah(1263-1328 M). Ia mengungkapkan bahwa ajaran Islam

5 Mohamed Elewa Badar, "Islamic Law (Shari'a) and the Jurisdiction of International Criminal Court", Leiden Journal of International Law, Vol 24, 2011, h. 411.

${ }^{6} \mathrm{Niaz}$ A.Shah,"The Use of Force under Islamic Law", The European Journal of International Law Vol.24 No.1, 2013 h,343.

7 Lim Merlyna, "Radical Islamism in Indonesia and Its Middle Eastren Connections", Middle East Review of International Affairs,15.2,Juni 2011, h. 36. 
yang terdapat dalam Alquran dan Hadis seluruhnya adalah syariat Islam. ${ }^{8}$ Muhammad Ibn Abdul Wahab(1703-1792 M) berhasil meletakan formulasi Hukum Islam di Saudi Arabia sehingga mampu memberikan pengaruh kepada ulama-ulama Muslim di berbagai penjuru dunia yang pada akhirnya membawa faham ini ke negeri masing-masing.

Pandangan lain justru bertolak belakang dengan pandangan pertama. Menurut kelompok ini keberadaan bangsa Indonesia yang sangat heterogen mengharuskan adanya format khusus yang disesuaikan dengaan lingkungan masyarakat. Keragaman agama, budaya, maupun adat istiadat menjadi pertimbangan khusus dalam menemukan format yang tepat dalam merumuskan Hukum Islam di Indonesia. Pandangan kelompok ini setidaknya memiliki kesepemahaman dengan pendapat Muhammad Abduh yang menyatakan bahwa perlu adanya format baru dalam sistem hukum yang didasari atas keadaan masyarakat dan lingkungan sekitar. ${ }^{9}$ Dalam menafsirkan ulang fikih klasik, Abduh memberikan solusi melalui prinsip mas\}lah\}ah dan talfiq. Selain itu yang dibutuhkan saat ini adalah lembaga ijtihad yang bersifat lokal karena akan lebih memahami dan memiliki kewenangan yang kuat untuk menyelesaikan persoalan sesuai dengan keadaan umat Islam setempat. Akan menjadi kontra produktif jika yang dimunculkan adalah lembaga ijtihad internasional yang justru tidak akan mampu memahami persoalan di setiap masyarakat. ${ }^{10}$

Kelompok kedua ini mencoba untuk lebih bersifat realistis mengingat kondisi negara Indonesia yang sangat heterogen dalam keberagamaan. Format Hukum Islam yang akan dimunculkan haruslah format yang mampu menghilangkan kecurigaan dari kelompok di luar Islam akan terjadinya proses "Islamisasi" dan juga mampu meyakini terhadap kelompok Islam yang lain sebagai

\footnotetext{
8 Yusril Ihza Mahendra, "Hukum Islam dan Pengaruhnya Terhadap Hukum Nasional Indonesia", http;// www.yusril.ihzamahendra.com.

9 Oliver Scharbordt \& Mark Sedgwick, "Muhammad Abduh", Bulletin of the School of Oriental and African Studies, University of London 73.2 Juni 2010, h. 320.

${ }^{10}$ Harun Nasution,Ijtihad Sumber Ketiga Ajaran Islam, Bandung:Mizan,1996 h. 15.
} 
jawaban serta solusi atas berbagai persoalan kontemporer yang dihadapi. ${ }^{11}$ Organisasi NU dan Muhammadiyah berada dalam kelompok ini.

Hasbi Ash Shiddieqy mengatakan perlunya Hukum Islam yang cocok dengan kebutuhan umat Islam Indonesia agar tidak menjadi asing bagi masyarakat muslim dan menjadi sesuatu yang "antik" sehingga hanya sebatas pajangan. ${ }^{12}$ Apabila Hukum Islam yang menjadi kebutuhan umat Islam dapat terwujud maka dapat menjadi penyangga bagi perumusan hukum nasional Indonesia. Hukum Islam dalam pengertian ini adalah fikih lokal sesuai ijtihad dan kondisi lingkungan serta masyarakat setempat yang ditetapkan oleh lembaga yang berwenang. Dengan demikian, Hukum Islam dalam prakteknya akan memiliki perbedaan antara satu negara dengan negara lainnya. Meskipun demikian ada batasan yang tetap harus disepakati bersama bahwa Hukum Islam tetaplah bersumber dari Alquran dan Sunnah yang tersimpul dalam maqa>s\}id al-shari' ah. ${ }^{13}$

\section{Dinamika Hukum Islam Sebagai Hasil ljtihad}

Ijtihad sebagai suatu upaya untuk mencari dan menemukan hukum dapat dilakukan dengan beberapa metode sebagaimana telah diuraikan di atas, yakni penfasiran, analogy atau qiyas, serta istihsan. Metode-metode ini dipergunakan karena tidak semua sendi-sendi kehidupan manusia diatur secara terperinci dalam al Qur'an dan Sunnah. Oleh karena itu menjadi keniscayaan untuk terus berupaya mencari dan menemukan hukum. Dalam upaya untuk mencari dan menemukan hukum yang belum diatur secara detail dalam Alquran dan Sunnah, maka seorang mujtahid dituntut untuk terlebih dahulu memahami secara baik teks-teks Alqurandan juga Sunnah. Karena jangan sampai hukum yang dihasilkan justru bertolak belakang

\footnotetext{
${ }^{11}$ Kristen Stilt, Islamic Law in Action:Authority, Regulation, and Everyday Experiences in Mamluk. Egypt, (London: Oxford University Press, 2011)

12 Nourouzaman Shiddiqi,Fiqh Indonesia: Penggagas dan Gagasannya, (Yogyakarta:Pustaka Pelajar,1997) h. 215.

${ }^{13}$ Jennifer F.Cohen, "Islamic Law in Iran: Can it Protect the International Legal Right of Freedom of Religion and Belief?", Chicago Journal of International Law;Summer 2008; Vol.9, h.1.
} 
dengan Alquran maupun Sunnah. Pemahaman terhadap teks-teks Alquran maupun Sunnah harus didahului dengan pemahaman tentang sebab-sebab turunnya ayat maupun Sunnah, sehingga dalam melakukan penafsiran tidak menyimpang. Selain itu juga pra syarat untuk dapat berijtihad adalah memahami dengan baik tata bahasa Arab, baik dalam ilmu nahwu, sharaf, balaghoh dan lainnya. Selain menggunakan teknik menafsirkan ayat Alquran atau teks Sunnah dalam berijtihad, maka teknik yang berikutnya dengan menggunakan analogy atau qiyas. Maksudnya adalah suatu persoalan yang telah ditetapkan secara hukum, baik oleh Alquran dan/ atau Sunnah, maka dapat dianalogikan dengan persoalan lain yang memiliki kemiripan. Hal ini dikarenakan adanya perkembangan peradaban manusia yang begitu cepat sehingga menjadi suatu kebutuhan untuk dapat menjawab berbagai persoalan kontemporer saat ini.

Keleluasaan untuk dapat berijtihad sepatutnya tidak disalahgunakan untuk kepentingan-kepentingan di luar hukum itu sendiri. Karena manakala proses ijtihad telah dipengaruhi oleh kepentingan-kepentingan di luar hukum, seperti politik, ekonomi dan lain sebagainya, maka dapat dipastikan hasil ijtihad itu akan mendapat penolakan dari masyarakat luas. Ijtihad harus diposisikan sebagai cara untuk mendapatkan sebuah penetapan hukum yang sejalan dengan al Alquran dan Sunnah bukan demi kepentingan di luar hukum.

Ada beberapa metode ijtihad yang dapat dilakukan guna tercapainya tujuan ijtihad sebagai penetapan hukum. Ketiadaan hukum yang disebabkan karena tidak diaturnya suatu persoalan dalam al Alquran dan Sunnah, menjadi pintu masuk untuk melakukan ijtihad agar tidak terjadi kekosongan hukum. Proses ijtihad guna mencegah terjadinya kekosongan hukum setidaknya dapat dikategorisasikan menjadi 4 bagian ${ }^{14}$. Pertama, adalah ijma

14 Sayyid Abul Ala Mawdudi, The Role of Ijtihad and Its Scope in Islam, Conceptual and Methodological Issues in Islamic Research: a Few Milestone (Kuala Lumpur, Dewan Bahasa dan Pustaka, 1996), h.127. 
ulama atau ijtihad kolektif. Yaitu kesepakatan seluruh ulama Islamatau setidaknya mayoritas (jumhur ulama)- dalam menentukan sesuatu persoalan ijtihadiyah. Kedua, ijtihad yang dilakukan oleh individu -individu tertentu yang memenuhi syarat berijtihad. Hasil ijtihad individu tersebut dijadikan rujukan atau referensi bagi sekelompok masyarakat yang se ide dengan sang mujtahid tersebut. Sebagai contohnya adalah ijtihad yang dilakukan oleh Imam alShafi'i, Maliki, Abu Hanifah, serta Ahmad bin Hanbal yang diikuti oleh sekelompok masyarakat muslim, yang selanjutnya dikenal sebagai mazhab. Ketiga, Keputusan suatu pemerintahan atau pemimpin yang mengadopsi sebagian atau seluruh hasil ijtihad dari para mujtahid untuk dijadikan sebagai hukum resmi negara tersebut. Misalnya apa yang dilakukan oleh dinasti Ottoman yang menggunakan mazhab Hanafi sebagai hukum resmi. Keempat, lembaga-lembaga dalam suatu negara yang memberlakukan hasil ijtihad para mujtahid sebagai landasan hukum dalam memutuskan atau menetapkan suatu persoalan. Bagian dari hasil ijtihad tersebut dijadikan sebagai fatwa oleh para ulama untuk menjawab pertanyaan atau memenuhi keinginan para pencari fatwa. Lembaga peradilan merupakan salah satu lembaga negara yang menggunakan cara ini dalam memutuskan perkara yang ditangani oleh para hakim (qadi). Namun demikian hasil keputusan para hakim tersebut tidak serta merta menjadi rujukan hukum bagi kasus-kasus selanjutnya karena dalam sistem hukum Islam sangat tidak dikenal (asing) istilah yurisprudensi (judge made law).

Artikel ini menyajikan persoalan yang telah lama ada di negara Indonesia, yakni mencari format ideal terkait dengan keberadaan Hukum Islam dalam hukum positif di Indonesia. Sejak Indonesia menjadi sebuah negara merdeka pada tahun 1945, sesungguhnya persoalan yang sangat mendasar sebagai sebuah negara yang majemuk telah ada di hadapan mata. Keberadaan Jakarta Charter yang awalnya merupakan bagian dari Pembukaan UUD 1945 menjadi sebuah tanda bahwa begitu kuatnya keinginan sebagian pendiri bangsa ini untuk menjadikan Hukum Islam sebagai hukum 
positif. Namun kesadaran akan kepentingan yang jauh lebih besar sebagai sebuah bangsa yang penuh dengan kemajemukan lebih diutamakan. Oleh karenanya hukum yang telah hidup di masyarakat muslim Nusantara sejak lama ${ }^{15}$ perlu untuk diformat ulang sehingga tidak bertentangan dengan kemajemukan masyarakat Indonesia .

Begitu beranekaragamnya suku bangsa di Nusantara menjadi sebuah kekuatan yang sangat dahsyat di satu sisi, namun di sisi lain menjadi sebuah ancaman nyata apabila tidak bisa dicari titik persamaan diantara mereka. ${ }^{16} \mathrm{Hal}$ inilah yang menjadi kekhawatiran, bahwa secara historis Hukum Islam tidak memiliki pengalaman yang memadai jika harus bersinggungan secara langsung dengan konsep negara modern saat ini. ${ }^{17}$

Konteks keberagaman mazhab yang dianut oleh organisasiorganisasi kemasyarakatan Islam, seperti Nahdlatul Ulama, Muhammadiyah, Persis, dan lainnya menjadikan begitu banyaknya landasan hukum yang harus diperhatikan. Menjadi hal yang wajar apabila gagasan-gagasan yang terdapat dalam mazhab-mazhab tersebut diperjuangkan agar dapat diberlakukan, seperti yang terjadi dibeberapa negara yang mengadopsi salah satu mazhab tertentu dalam hukum poistifnya. ${ }^{18}$ Apalagi secara historis keberadaan organisasi kemasyarakatan Islam tersebut telah lebih dulu berdiri dibandingkan kemerdekaan Indonesia.

Konsep unifikasi modern antara syariah dan Pemerintah telah coba dirumuskan oleh Ibn al-Muqaffa' yang mengusulkan adanya sebuah ketentuan yang berlaku bagi semua warga masyarakat yang bersumber dari Alquran dan Sunnah. ${ }^{19}$ Oleh karenanya kodifikasi

\footnotetext{
15 Mark E.Cammack \& R.Michael Feener, The Islamic Legal System in Indonesia, Pacific Rim Law \& Policy Journal, Vol.21, No.1, January 2012,h. 15-16.

${ }^{16}$ John R.Bowen, Islam,Law, and Equality in Indonesia : an Anthropogy of Public Reasoning,( Cambridge: Cambridge University Press, 2003),h. 1- 5.

17 Cipto Sembodo, Reintroduksi Hukum Islam dalam Wacana Kebangsaan, UNISIA, Vol.XXXI No.69 September 2008, h. 232.

${ }_{18}$ Guy Burak, The Second Formation of Islamic Law: The Post-Mongol Context of the Ottoman Adoption of a School of Law, Comparative Studies in Society and History 2013;55(3) h. 602.

${ }^{19}$ Joseph E.Lowry, The First Islamic Legal Theory: Ibn al-Muqaffa on Interpretation, Authority, and the Structure of the Law, Journal of the American Oriental Society, 128.1 2008, h. 25.
} 
dan legislasi hukum menjadi sebuah tuntutan yang objektif dan mendesak. ${ }^{20}$ Akan menjadi persoalan yang berlarut-larut apabila tidak ada kejelasan tentang pihak manakah yang memiliki otoritas resmi untuk dijadikan sebagai legislator ${ }^{21}$ dalam sebuah negara yang mayoritas penduduknya beragama Islam, seperti Indonesia.

Upaya untuk menjadikan Hukum Islam sebagai bagian dari hukum positif di Indonesia sesungguhnya telah dimulai sejak awal kemerdekaan, baik di masa sistem pemerintahan berbentuk presidensil maupun saat parlementer, seperti yang diupayakan oleh Menteri Agama saat itu, Saifudin Zuhri, yang memberikan rancangan undang-undang tentang zakat kepada DPRGR dan beberapa kementerian namun tidak mendapatkan respon. ${ }^{22}$

Dalam sejarah perundang-undangan pasca Indonesia merdeka, baru pada tahun 1974 berhasil dirumuskan satu peraturan perundang-undangan yang penuh dengan nilai-nilai Islam dan bersifat unifikasi.23 Momentum tersebut menjadi pertanda dimulainya Hukum Islam menjadi bagian dari hukum positif di Indonesia. Berturut-turut pada tahun 1989 dengan dikeluarkannya Undang-undang tentang Peradilan Agama, lalu pada tahun 1991 dikeluarkannya Instruksi Presiden nomor 1 tahun 1991 tentang Kompilasi Hukum Islam (KHI). Perubahan paradigma yang cukup besar terjadi di sepuluh tahun terakhir masa pemerintahan Orde Baru.

20 Wahiduddin Adams, Legislasi Hukum Islam dalam Perspektif Fiqh, Pesantren, Vol.VII,No.2, 1990, h. 233.

21 Mawil Izzi Dien, Islamic Law from Historical Foundations to Contemporary Practice, Sixteenth Century Journal XXXVII/3 2006, 912. Lihat juga Clark B. Lombardi, Designing Islamic constitutions: Past Trends and Options for a Democratic Future, $I \bullet C O N$, Vol. 11 No. 3,2013, h. 619.

22 Arskal Salim, The Influential Legacy of Dutch Islamic Policy on the Formation of Zakat (Alms) Law in Modern Indonesia, Pacific Rim Law \& Policy Journal, Sep 2006, Vol 15 No 3, h. 694.

${ }^{23}$ Amak F.Z., Proses Undang-undang Perkawinan, (Bandung: Al-Ma'arif. 1976), h.35-48. 


\section{Kompilasi Hukum Islam}

Menurut Black's Law Dictionary, kompilasi (compilation) mengandung arti suatu produk berbentuk tulisan hasil karya orang lain yang disusun secara teratur (Compilation: a literary production composed of the works of others and arranged in methodical manner). Dengan demikian KHI merupakan himpunan ketentuan Hukum Islam yang dituliskan dan disusun secara teratur. KHI bukanlah peraturan perundang-undangan, bukan hukum tertulis meskipun dituliskan, bukan undang-undang, bukan peraturan pemerintah. ${ }^{24}$

Dari segi posisinya dalam tatanan hukum nasional $\mathrm{KHI}$ merupakan hukum Islam legal-formal karena tertuang dalam Instruksi Presiden No. 1 tahun 1991, artinya KHI merupakan produk negara orde baru. Menurut Moh. Mahfud M.D. karakter suatu hukum senantiasa dipengaruhi atau ditentukan oleh konfigurasi politik suatu kelompok dominan (penguasa) selalu melahirkan karakter produk hukum tertentu sesuai dengan visi politiknya. ${ }^{25}$ Dengan demikian dari sisi legal-formal dan substasi materriilnya, KHI tidaklah lepas dari persoalan tersebut.

Gagasan dimunculkannya KHI pertama kali disampaikan oleh Bustanul Arifin, meskipun ada pendapat lain yang menyebutkan penggagas awal KHI adalah Munawir Syadzali. Berpijak dari proses pembentukan dan adanya dominasi di dalam proses pembentukan KHI tersebut memberi arti bahwa dibalik wacana KHI sebagai pembaharuan hukum Islam kontemporer keindonesiaan ada pula wacana Intervensi politik hukum orde baru yang nota bane terpinggirkan. Hal demikian terlihat jelas dari bahasa KHI sendiri bahwa kodifikasi dan unifikasi sebagai model pembaharuan KHI adalah mengarah pada pembangunan hukum nasional. ${ }^{26} \mathrm{Hal}$ tersebut sesuai dengan apa yang diamanatkan GBHN. Intervensi tersebut

${ }^{24}$ Amrullah Ahmad SF dkk, Hukum Islam dalam Sistem Hukum Nasional (Jakarta: Gema Insani Press,1996),h.152.,

25 Moh. Mahfudz MD., Konfigurasi Politik dan Hukum Pada Era Orde Baru dan Orde Lama, dalam Khamami Zada dan Idy Muzayyad (ed.), Wacana Politik Hukum dan Demokrasi Indonesia (Yogyakarta : Pustaka Pelajar, 1999), h 29

${ }^{26}$ Kompilasi Hukum Islam Indonesia (Jakarta : Dirjen Binbaga Islam Depag, 1992), h. 126. 
bukanberarti menafikan unsur-unsur Islam yang sedikit banyak mewarnai proses pembentukan KHI, meskipun keterlibatannya pasif.

Pada tahun 1985 tim pelaksana proyek pembentukan Kompilasi Hukum Islam lewat SKB Ketua MA RI dan Menteri Agama RI No.07/KMA/1985 dan No.25/1985 tanggal 25 Maret 1985,76 yang merupakan kelanjutan dari SK. Ketua MA No.04/KMA/1976 tentang PANKER MAHAGAM yaitu Panitia Kerjasama Mahkamah Agung/Departemen Agama yang telah banyak mengadakan simposium dalam rangka penyeragaman tindak MA dan DEPAG untuk menghindariperbedaan penafsiran tentang Undang-undanU No.1/1974.77proses yang demikian adalah proses pendekatan struktural yang bersifat up down. SKB tersebut selanjutnya menjadi dasar hukum bagi kerja-kerja penyusunan KHI berikutnya. Berdasarkan SKB tersebut dari personil kepanitiaan menunjukkan adanya dominasi MA dan DEPAG dari 16 personil kepanitiaan. Secara kuantitatif dapat dilihat bahwa 1 personil dari MUI yakni KH. Ibrahim Hussein, LML., 8 personil MA dan 7 personil DEPAG. Kemudian juga berdasarkan SKB tersebut segala kebijakan berkaitan dengan proyek pembentukan KHI dan pelibatanberbagai pihak yang dirasa berkepentingan dalam hal ini sepenuhnya menjadi tanggungjawab tim pelaksana proyek. Hal demikian berarti partisipasi aktif kelompok sosial umat Islam dalam pembaharuan hukum Islam tenggelam oleh ciri pemerintahan orde baru sebagai rezim otoriter yang ikut mewarnai di dalamnya.

KHI itu sendiri merupakan rangkuman dari 38 kitab yang telah dikaji oleh tim pembentuk KHI guna mencari format Hukum Islam yang dapat diterapkan di Indonesia. Adapun dari ke 38 kitab yang diteliti tersebut didominasi oleh mazhab Safei'i yang berjumlah 28 kitab, lalu mazhab Maliki berjumlah 2 kitab, mazhab Hanafi berjumlah 2 kitab, mazhab Hanbali berjumlah 2 kitab, mazhab Zahiri 1 kitab, dan kumpulan dari berbagai mazhab berjumlah 3 kitab. ${ }^{27}$

27 Andre Feillard, NU Via-A-Vis Negara; Pencarian Isi Bentuk dan Makna (Yogykarta : LKiS, 1999), h.390. 


\section{Hukum Islam di Era Reformasi}

Jatuhnya Presiden Soeharto di tahun 1998 tidak hanya berimplikasi pada proses suksesi kepemimpinan nasional, namun juga terkait dengan munculnya kembali keinginan dari sebagian masyarakat Indonesia untuk kembali menghidupkan syariah dalam berbagai aspek kehidupan berbangsa dan bernegara. ${ }^{28}$ Mulai dari UU Zakat, UU Perbankan Syariah, UU Wakaf, amandemen UU Peradilan Agama, hingga pemberlakuan qanun di Aceh. Banyaknya peraturan perundang-undangan bernuansa syariah yang dihasilkan pasca reformasi tidak terlepas dari peran partai-partai politik Islam yang berhasil masuk ke DPR sejak pemilu 1999.29 Perkembangan perpolitikan Indonesia di masa reformasi memberikan tempat bagi partai politik Islam untuk dapat memperjuangkan aspirasi umat Islam. Kondisi demokratis ini memberikan harapan baru bagi perkembangan Hukum Islam dalam konstelasi hukum positif di Indonesia, termasuk dalam bidang ekonomi Islam. ${ }^{30}$

Ekonomi Islam, menurut para ahli dikatakan sebuah sistem ekonomi yang dibangun atas prinsip-prinsip religius, berorientasi pada persoalan dunia maupun akhirat. Mayoritas para ekonom muslim sepakat mengenai dasar filosofis sistem ekonomi Islam yaitu: Tauhid, Khilafah, 'Ibadah, dan Takaful. ${ }^{31}$ Sistem ekonomi dan keuangan Islam adalah sistem yang senantiasa mengacu pada maqas\{id alshari'ah, sesuai dengan tujuannya yakni kemaslahatan.

Pada tataran konsep dan ide, sistem ekonomi syariah memiliki prinsip-prinsip yang berbeda dengan sistem ekonomi lainnya seperti kapitalisme dan sosialisme. Masudul Alam Choudury mengemukakan beberapa prinsip utama dari sistem ekonomi Islam yakni prinsip tauhid dan persaudaraan, prinsip bekerja dan

28 Arskal Salim, Challenging Secular State: The Islamization of Law in Modern Indonesia (Honolulu:University of Hawaii Press,2008),119.

29 Sunny Tanuwidjaja, Political Islam and Islamic Parties in Indonesia: Critically Assesing the Evidence of Islam's Political Decline, Contemporary Southeast Asia, Vol. 32, No. 1, 2010, 32.

${ }^{30}$ Fatima Z Rahman, Determinants of Determinants of Democracy in the Muslim World, Polity, Vol 45, No 4, October 2013,578.

31 Mohammed Aslam Haneef, Contemporary Islamic Economic Thought: A Selected Comparative Analysis (Kuala Lumpur: Ikraq, 1995),2. 
produktivitas, dan distribusi equitas. ${ }^{32}$ Sementara Naqvi menjelaskan empat landasan normatif dalam etika Islam yang direpresentasikan dalam aksioma etika yaitu landasan tauhid, keadilan, kehendak bebas, dn pertanggungjawaban.33 Tokoh lainnya, Humaid al-'Ali menyebutkan tiga ciri utama ekonomi syariah yaitu : (1) ekonomi ilahi-rabbani-'aqdi; (2) ekonomi ta'abbudi akhlaqi dan (3) ekonomi insani'alami-waqi'i. ${ }^{34}$ Meskipun pada tataran teori dan konsep para ahli mengemukakan perincian yang bebeda mengenai karakteristik ekonomi syariah, namun pada dasarnya terdapat persamaan diantara mereka, yakni mengutamakan nilai-nilai etika dan moral, yakni terhindar dari maisir, gharar, riba, ${ }^{35}$

Namun disisi lain, munculnya peraturan perundang-undangan yang bernuansa syariah tersebut memunculkan kekhawatiran bagi sebagian masyarakat non muslim Indonesia-bahkan dunia- akan pemberlakuan syari'ah Islam di Indonesia. ${ }^{36}$ Tidak dapat disalahkan jika ada kekhawatiran yang dirasakan oleh sebagian masyarakat non muslim terkait dengan fenomena maraknya peraturan perundangundangan bernuansa syar'riah karena melihat arah dari konsep yang coba dikembangkan oleh para legislator di beberapa daerah di Indonesia lebih kearah bentuk model hukuman seperti ta'zir dan hukuman fisik lainnya dan bukan pada substansi yang dapat diterima oleh semua masyarakat, baik yang muslim maupun non muslim $^{37}$.

\footnotetext{
32 Masudul 'Alam Choudhury, Contribution to Islamic Economic Theory: A Study in Social Economic (New York: ST Martin’s Press, 1986), h.7-10.

33 Syed Nawab Haider Naqvi, Islam, Economic and Society (London: Kegan Paul International: University Michigan, 1994), h.27. 32.

${ }^{34} \mathrm{H}$ \} umaid al-'Ali, Ma'alim al-Iqtisad al-Islami, (Beirut: Dar al-Thaqafah, 1998), Jilid I, .h.31-

35 A.Gait dan A.C Worthington, "A Principle on Islamic Finance: Definition, Source, Principles and Methode", Journal of Faculty of Commerce-University of Wollonggong (2007), h. 7.

36 Andrea Büchler Islamic Family Law in Europe? From Dichotomies to Discourse or:Beyond Culturaland Religious Identity in Family Law, International Journal of Law in Context, 8, 2, $2012,1$.

37 Topo Santoso, Implementation of Islamic Criminal Law in Indonesia: Tanzor Punishment as a Solution?, IIUM Law Journal, Vol. 19 ,No. 1, 2011 ,149
} 


\section{Hukum Islam Dalam Kemajemukan}

Kemajemukan adalah salah satu masalah utama yang harus dihadapi dalam menyikapi gagasan untuk merumuskan format legalisasi Hukum Islam. Dalam perkembangannya saat ini kemajemukan bangsa bersanding dengan persoalan lainnya yakni pluralism agama, baik secara teoritis maupun filosofis. Format hukum yang mampu menjembatani diantara berbagai pandangan yang hidup dan tumbuh di Indonesia seharusnya menjadi catatan terpenting dalam proses perumusan format hukum nasional. Kemajuan serta perkembangan faham yang senantiasa bergulir tidak dapat dinafikan sebagai akibat adanya globalisasi. ${ }^{38}$ Konsep maqa>s\}id al-Shari>'ah yang mengutamakan keadilan, non diskriminasi, kesamaan hak menjadi prinsip universal yang dapat diterima semua golongan di dalam kemajemukan suatu masyarakat. Berdasarkan hal tersebut maka kemajemukan yang dimiliki oleh bangsa Indonesia tidak menjadi penghalang dalam upaya untuk mencari format terbaru dalam merealisasikan Hukum Islam yang mengayomi seluruh kelompok maupun golongan.

\section{Rekonsepsi Hukum Islam di Indonesia}

Berbagai konsep yang akan diajukan dalam upaya mengembangkan Hukum Islam di Indonesia setidaknya harus melihat juga sejarah perkembangan tradisi dan pemikiran Islam yang telah lama ada. ${ }^{39}$ Dalam sejarah Hukum Islam pemikiran hukum yang dihasilkan oleh para ulama "swasta" lebih dapat diterima oleh masyarakat dibandingkan hasil pemikiran hukum "negeri". ${ }^{40}$ Hal ini dapat dilihat dari banyaknya kitab-kitab fiqih yang dijadikan rujukan utama masyarakat dibandingkan dengan warisan

38 Andreas Hasenclever \& Volker Rittberger, "Does Religion Make ADifference?: Theoritical Approaches to the Impacts of Faith on Political Conflicts", Millenium:Journal of International Studies, ol.29, no.3, 2000, .642

39 Azyumardi Azra, Renaisan Islam Asia Tenggara Sejarah Wacana dan Kekuasaan ( Bandung: Rosdakarya, 1999) Cet. I.

40 Muhammad Atho Mudzhar, Social History Approach to Islamic Law, al-Jami'ah Journal of Islamic Studies, No. 61, 1998. 
keputusan pengadilan agama bahkan aturan negara. Berdasarkan hal tersebut, maka patutlah dipertimbangkan persoalan-persoalan apa saja yang layak untuk diatur oleh negara. Karena bagaimanapun juga tidak seharusnya semua persoalan kehidupan masyarakat diatur oleh negara, apalagi yang terkait dengan praktek-praktek keagamaan atau hukum diyani ${ }^{41}$. Campur tangan negara yang terlalu dominan dalam penerapan hukum agama akan menimbulkan anggapan otoriternya hukum agama tersebut.

Konsep kehidupan bernegara di Indonesia sebagai sebuah negara hukum (rechtstaat) harus dimaknai bukan sebagai negara Hukum Islam. Namun menyikapi hukum yang hidup di Indonesia pada kenyataannya ada Hukum Islam di tengah masyarakat harus pula disikapi secara baik .Keikutsertaan negara dalam merumuskan sebuah peraturan merupakan hal yang mutlak. Karena kebebasan yang tanpa batas dalam konteks perumusan serta penetapan sebuah peraturan perundang-undangan hanya akan menimbulkan anarkis berlabel agama, dan hal ini justru sangat merugikan agama itu sendiri. Dalam upaya untuk merumuskan hukum agama (Islam) inilah, negara (pemerintah) harus mampu mengedepankan substansi dari hukum agama (Islam) dibandingkan dengan label penamaan "syari'ah". Berbagai teori terkait dengan keberadaan Hukum Islam di Indonesia, mulai teori Receptie in Complexu milik Van den Berg, lalu teori Receptie milik Snouck Hurgronje, teori Receptie Exit milik Hazairin, teori Receptie a Contrario milik Sayuti Thalib, teori Eksistensi miliknya Ichtijanto dan pemikiran Hasbi ash-Shidiqiey dan Munawir Syadzali $^{42}$ harus dijadikan pertimbangan di saat negara akan merumuskan berbagai nilai-nilai Islam untuk dijadikan hukum positif.

Pemahaman akan Hukum Islam yang diformulasikan sebagai hukum positif di Indonesia, seharusnya dipahami sebagai "fiqih"

\footnotetext{
${ }^{41}$ Rifyal Ka’bah, Reformasi Metodologi Pengembangan Hukum Islam, Mimbar Hukum : Aktualisasi Hukum Islam,Jakarta, DITBINBAPERA, No. 43,Tahun X, 1999.

${ }^{42}$ Euis Nurlaelawati, Modernization, Tradition and Identity : The Kompilasi Hukum Islam and Legal Practice in the Indonesian Religious Courts, ( Amsterdam: Amsterdam University Press, 2010) h. 7580.
} 
yang memungkinkan untuk disesuaikan dengan tempat dan waktu. Penggunaan label "syari'ah" setidaknya memunculkan kerancuan di sebagian masyarakat yang mengidentikan atau menyamakan dengan sumber utama Hukum Islam, yakni Alquran dan Sunnah, yang tidak boleh untuk dirubah. Akibatnya akan menimbulkan salah persepsi manakala ada perubahan penafsiran dari sebuah ketentuan yang sebelumnya telah ada. Jika dilihat perbedaan antara syari'ah dan fiqih, maka setidaknya dapat dikategorikan menjadi 3 , yaitu bahwa syari'ah adalah (1) konteks agama secara umum; (2) konteks hukum secara umum; dan (3) bersumber dari kitab suci dan hadits, berbeda dengan fiqih yang bersumber dari penafsiran manusia. ${ }^{43}$

Berdasarkan hal tersebut, maka menjadi sangat wajar apabila dalam perkembangan Hukum Islam di Indonesia disesuaikan dengan konteks keadaan masyarakatnya, baik waktu maupun tempatnya. Hal inilah yang menjadi substansi penting bagi perumusan Hukum Islam di Indonesia yang dapat menjawab berbagai kebutuhan masyarakat muslim di Indonesia. Agenda perumusan Hukum Islam di Indonesia harus mampu mengangkat martabat manusia, karena hal itulah yang sesungguhnya dimaksudkan dalam filsafat Islam terkait dengan keberadaan sebuah hukum. Salah satu agenda yang relevan dengan tujuan tersebut adalah pengaturan dalam bidang mu'amalah guna menghilangkan kesenjangan ekonomi dan sosial yang semakin tinggi.44 Perkembangan masyarakat yang sangat cepat, seringkali mampu meninggalkan aturan-aturan dalam Hukum Islam. Berbagai problematika kontemporer seharusnya mampu diimbangi dan dicarikan solusinya oleh perkembangan Hukum Islam. Oleh karenanya Hukum Islam harus mampu bergerak dinamis mengikuti kebutuhan masyarakatnya. Konteks mu'amalah yang terus mengalami perkembangan menuntut adanya interaksi antara penafsiran Hukum Islam dengan masyarakat secara terus-menerus.

43 Mashood Baderin, Understanding Islamic Law in Theory and Practice, Legal Information Management,9, 2009, h.186-187.

${ }_{44}$ Nasaruddin, Umar, Konstitusionalisasi Hukum Islam di Indonesia, Jurisdiksi, Edisi I,Vol. I, 1996. 
Tanpa adanya interaksi yang berkesinambungan, maka akan sangat sulit bagi Hukum Islam untuk dapat menjawab kebutuhan masyarakat yang pada akhirnya diformulasikan dalam hukum positif di Indonesia. 45

Di undangkannya UU perbankan syari'ah, wakaf, zakat, perkawinan, peradilan agama dan Kompilasi Hukum Islam merupakan beberapa contoh hasil dari sebuah interaksi antara Hukum Islam dengan masyarakat. Dari beberapa contoh UU tersebut dapat terlihat adanya fleksibilitas penerapan ide dan gagasan yang bersumber dari berbagai mazhab yang ada. Pemberlakuan mazhab tertentu dalam konteks perumusan Hukum Islam tentunya akan mempersulit untuk mendapatkan konsep yang tepat seiring dengan semakin beragamnya problematika masyarakat. Berdasarkan hal tersebut, takhayyur (eclectic expedient) kebebasan untuk menggunakan berbagai mazhab menjadi kebutuhan saat ini. ${ }^{46}$ Oleh karenanya dalam mencari formulasi Hukum Islam yang tepat dengan kebutuhan masyarakat saat ini, maka proses ijtihad tidak dapat lagi dibatasi hanya pada mazhab tertentu. Bahkan tidak ada kewajiban hanya berpedoman pada satu mazhab tertentu. ${ }^{47}$

\section{Paradigma Positivisme}

Kesadaran akan kebutuhan adanya rekonstruksi dalam Hukum Islam di Indonesia tidak hanya berpijak pada tatanan fiqih nya namun juga memperhatikan rekonstruksi paradigma positivisme dalam ilmu hukum. Rekonstruksi itu dipahami sebagai berikut: Pertama, harus disadari bahwa saat ini kita hidup di abad 21 atau abad digital, maka perlu menyikapi dengan pemahaman yang bersifat digital thinking, dan patut menyadari pemberlakuan sebuah Undang-Undang negara jangan hanya ditujukan kepada kepastian

\footnotetext{
${ }^{45}$ Fathurrahman, Djamil, Reaktualisasi dan Legislasi Hukum Islam di Indonesia, Jurisdiksi, Edisi I, Vol. I, 1996.

${ }^{46}$ N.J.Coulson, A History of Islamic Law (Edinburgh University Press,1964),185. Norman Anderson, Law Reform in The Muslim World (London:The Atlones Press,1976) 47-48.

${ }^{47}$ Wahbah al-Zuhaili, al-Figh al-Isla $>$ mi $>$ wa Adillatubu, juz I (Beirut: Dar al-Fikr,2005), 74.
} 
hukum semata, tetapi harus mampu menangkap rasa keadilan masyarakat serta kemanfaatan bersama. ${ }^{48}$

Kedua, bahwa hukum yang bukan hidup diruang hampa, tetapi hidup dialam diantara manusia yang bersifat dinamis, oleh karena itu pemberlakuan undang-undang dari negara perlu memperhatikan kebutuhan dinamika manusia yang memerlukan kecepatan informasi dan pelayanan publik, oleh karena itu hal yang harus disiapkan adalah infra struktur yang mendukung dan program sosialisasi yang menjadi perhatian, karena tidak bisa mengandalkan fiksi hukum saja sebagai ciri positivisme.

Ketiga, suka atau tidak suka dibutuhkan SDM yang profesional untuk memberlakukan sebuah Undang-Undang negara, oleh karena itu perlu diserap SDM yang berbasis spiritualitas, oleh karena itu perekrutan SDM dibidang ini perlu memperhatikan moralitas yang diseleksi dari penyedia SDM yang berbasis dari Pendidikan yang berstandar nasional dan internasional, karena SDM yang dibutuhkan berbanding lurus dengan semangat serta latar belakang dan tujuan diberlakukan sebuah undang-undang.

Keempat,Perlu pergeseran Paradigma penegakan hukum, sebagaimana Sinzheimer mengatakan bahwa hukum tidak bergerak dalam ruang yang hampa dan berhadapan dengan hal-hal yang abstrak. Melainkan, ia selalu berada dalam suatu tatanan sosial tertentu dan manusia-manusia yang hidup. Jadi bukan hanya bagaimana mengatur sesuai dengan prosedur hukum, melainkan juga bagaimana mengatur sehingga dalam masyarakat timbul efekefek yang memang dikehendaki oleh hukum. Dengan demikian masalah efiesiensi suatu peraturan hukum menjadi sangat penting. Oleh karena menyangkut pula kaitan-kaitan lain dalam berpikirnya, yaitu meninjau hubungan hukum dengan faktor-faktor serta kekuatan- kekuatan sosial diluarnya. Hal ini jelas dikatakan pula oleh Robert B. Seidman, bahwa setiap undang-undang, sekali dikeluarkan

48 Clark B.Lombardi, Designing Islamic Constitutions: Past Trends and Options for a Democratic Future, Oxford University Press and New York University School of Law, 2013. 
akan berubah, baik melalui perubahan normal maupun melalui caracara yang ditempuh birokrasi ketika bertindak dalam bidang politik, ekonomi, sosial dan sebagainya.

Tidak dapat disangkal lagi bahwa perkembangan masyarakat yang susunannya sudah semakin kompleks serta berkembang, mengkehendaki peraturan hukum juga harus mengikuti perkembangan yang demikian itu. Hampir setiap bidang kehidupan sekarang ini kita jumpai dalam peraturan hukum. Hukum menelurusi hampir semua bidang kehidupan manusia. Hukum semakin memegang peranan yang sangat penting sebagai kerangka kehidupan sosial masyarakat modern. Namun, harus disadari sungguh-sungguh bahwa masalah peraturan oleh hukum itu bukan saja dilihat dari segi legimitasinya, dan bukan juga semata-mata dilihat sebagai ekspresi dari nilai-nilai keadilan. Itulah sebabnya muncul suatu cara berpikir lain (aliran pemikiran non-analistis) yang tidak lagi melihat hukum sebagai lembaga yang otonom di dalam masyarakat, melainkan sebagai suatu lembaga yang bekerja untuk dan di dalam masyarakat. ${ }^{4}$

Kelima, Menyadari akan pergeseran peran hukum (hukum negara) yang demikian itu, maka agar "paradigma kekuasaan" yang dipakai dalam penegakkan hukum di Indonesia ini perlu diubah atau diganti dengan penegakan yang berbasis "paradigma moral". Paradigma moral yang diidealkan itu memiliki seperangkat nilai yang egalitarian, demokratis, pluralitis, dan profesional untuk membangun "masyarakat madani" (civil society). Perubahan paradigma ini penting dilakukan untuk memulihkan dan mengembalikan otentisitas hukum "sebagai sarana untuk memberikan kebahagiaan terbesar bagi sebanyak mungkin orang". 50

${ }^{49}$ Esmi Warassih, Pranata Hukum sebuah telaah Sosiologis,( PT Suryandaru Utama,2005). Lihat juga Soetandyo Wignjosoebroto, Hukum Dalam Masyarakat, Perkembangan dan Masalab (, Bayu Media, April, 2008).

50 Turiman, Memahami Hukum Progresif Prof Satjipto Rahardjo Dalam Paradigma "Thawaf" (Sebuah Komtemplasi Bagaimana Menniudkan Teori Hukum Yang Membumi / Grounded Theory MengIndonesia (Program Doktor Imu Hukum Universitas Diponogoro, 2010),h.34. 


\section{Penutup}

Berdasarkan penjelasan di atas maka dapatlah disimpulkan bahwa Semakin inklusif suatu peraturan, semakin efektif penerapannya di masyarakat. Pendapat Ibn al-Muqaffa yang menyatakan perlu adanya unifikasi peraturan yang berlaku bagi semua warga negara,termasuk peraturan yang bersumber dari Alquran dan Hadis sangat relevan dalam konteks unifikasi pertauran perundang-undangan dan kepastian hukum. Pemikiran dari Ibn alMuqaffa sebagai peletak dasar pertama dalam upaya melakukan unifikasi hukum agama dalam suatu negara menjadi pintu masuk dalam merumuskan format Hukum Islam yang dapat diterima tidak hanya oleh umat Islam namun juga umat lainnya. Adapun Robert B. Seidman,lebih memfokuskan bahwa sebuah peraturan akan sangat mungkin mengalami perubahan. Bahkan dikatakan bahwa setiap undang-undang, sekali dikeluarkan akan berubah, baik melalui perubahan normal maupun melalui cara-cara yang ditempuh birokrasi ketika bertindak dalam bidang politik, ekonomi, sosial dan sebagainya. Hal ini menunjukan bahwa menemukan formulasi atau konsep yang sesuai dengan keadaan masyarakat dan masa saat ini adalah keharusan. Sebab pada dasarnya Hukum Islam yang kita sepakati adalah fiqih yang merupakan hasil penafsiran dari para ulama, sehingga perbedaan pendapat serta perubahan menjadi keniscayaan. Di samping itu pula pencarian formulasi atau konsep Hukum Islam di Indonesia tidak hanya berhenti pada tatanan figh maupun ushul fighnya saja, namun juga memperhatikan paradigma hukum nasional yang berasaskan Pancasila.Muhammad Abduh sebagai salah satu pembaharu Hukum Islam meyakini bahwa konsep Hukum Islam di masa lalu akan sangat perlu dilakukan kajian ulang yang disesuaikan dengan kondisi lingkungan dan masyarakat saat ini.

\section{Pustaka Acuan}

Adams, Wahiduddin," Legislasi Hukum Islam dalam Perspektif Fiqh", Pesantren,, Vol.VII, No.2, 1990. 
Ahmad SF, Amrullah, dkk, Hukum Islam dalam Sistem Hukum Nasional Jakarta: Gema Insani Press,1996.

Al-Ati,H.Abd, The Family Structure in Islam, Indianapolis: ATP, 1977

Al-Zuhaili, Wahbah, al-Figh al-Islami wa Adillatuhu, juz I, Beirut: Dar al-Fikr,2005.

Amak F.Z., Proses Undang-undang Perkawinan, Bandung: Al-Ma'arif. 1976.

Azra, Azyumardi, Renaisan Islam Asia Tenggara Sejarah Wacana dan Kekuasaan, Bandung: Rosdakarya, 1999, Cet. I

Badar, Mohamed Elewa, "Islamic Law (Shari'a) and the Jurisdiction of International Criminal Court", Leiden Journal of International Law, vol 24, 2011

Baderin, Mashood,"Understanding Islamic Law in Theory and Practice", Legal Information Management, Vol 9, 2009.

Bowen, John R, Islam,Law, and Equality in Indonesia : an Anthropogy of Public Reasoning, Cambridge: Cambridge University Press, 2003

Büchler, Andrea, "Islamic Family Law in Europe? From Dichotomies to Discourse-or:Beyond Culturaland Religious Identity in Family Law", International Journal of Law in Context, 8, 2, 2012.

Burak, Guy, "The Second Formation of Islamic Law: The PostMongol Context of the Ottoman Adoption of a School of Law", Comparative Studies in Society and History 2013

Cammack,Mark E \& Feener, R.Michael, “The Islamic Legal System in Indonesia", Pacific Rim Law \& Policy Journal, Vol.21, No.1, January 2012.

Cohen, Jennifer F, "Islamic Law in Iran: Can it Protect the International Legal Right of Freedom of Religion and Belief?", Chicago Journal of International Law;Summer 2008;9,1.

Coulson, N.J, A History of Islamic Law (Edinburgh University Press,1964),185. Anderson,Norman, Law Reform in The Muslim World, London:The Atlones Press,1976

Depag, Kompilasi Hukum Islam Indonesia, Jakarta : Dirjen Binbaga Islam Depag, 1992 
Dien, Mawil Izzi, "Islamic Law from Historical Foundations to Contemporary Practice", Sixteenth Century Journal XXXVII/3 2006, 912.

Lombardi,Clark B, Designing Islamic constitutions: Past Trends and Options for a Democratic Future, $I \bullet C O N$, Vol. 11 No. 3,2013.

Djamil, Fathurrahman, "Reaktualisasi dan Legislasi Hukum Islam di Indonesia", Jurisdiksi, Edisi I, Vol. I, 1996.

El Shamsy, Ahmed, "Rethinking Taqlid in the Early Shafi'i School", Journal of the American Oriental Society $128.1,2008$.

Hasenclever, Andreas, \& Volker Rittberger, "Does Religion Make ADifference?: Theoritical Approaches to the Impacts of Faith on Political Conflicts", Millenium:Journal of International Studies, ol.29, no.3, 2000.

Ka'bah,Rifyal, "Reformasi Metodologi Pengembangan Hukum Islam", Mimbar Hukum: Aktualisasi Hukum Islam, Jakarta, DITBINBAPERA, No. 43,Tahun X, 1999.

Lim, Merlyna, "Radical Islamism in Indonesia and Its Middle Eastren Connections", Middle East Review of International Affairs,15.2,Juni 2011.

Lombardi, Clark B, Designing Islamic Constitutions: Past Trends and Options for a Democratic Future, Oxford University Press and New York University School of Law, 2013.

Lowry,Joseph E., “The First Islamic Legal Theory: Ibn al-Muqaffa on Interpretation, Authority, and the Structure of the Law", Journal of the American Oriental Society, 128.12008.

Mahendra,Yusril Ihza,"Hukum Islam dan Pengaruhnya Terhadap HukumNasionalIndonesia,http;/ / www.yusril.ihzamahendra.com

Mahmood,T, "Law in the Qur'an: A Draft Code", Islamic Comparative Law, Quarterly 1, 1987.

Mawdudi, Sayyid Abul Ala, The Role of Ijtihad and Its Scope in Islam, Conceptual and Methodological Issues in Islamic Research: a Few Milestone Kuala Lumpur, Dewan Bahasa dan Pustaka, 1996.

Mudzhar, Muhammad Atho, "Social History Approach to Islamic Law", al-Jami'ah Journal of Islamic Studies, No. 61, 1998. 
Nasution,Harun, Ijtihad Sumber Ketiga Ajaran Islam, Bandung:Mizan,1996.

Nurlaelawati, Euis, Modernization, Tradition and Identity: The Kompilasi Hukum Islam and Legal Practice in the Indonesian Religious Courts, Amsterdam: Amsterdam University Press, 2010.

Rahman,Fatima Z, "Determinants of Determinants of Democracy in the Muslim World", Polity, Vol 45, No 4, October 2013.

Ramadan, S, Islamic Law: Its Scope and Equity, London: Macmillan, 1970.

Reza, Sadiq, Due Process in Islamic Criminal Law, The George Washington International Law Review $46.1 \quad$ (2013).

Salim, Arskal, "The Influential Legacy of Dutch Islamic Policy on the Formation of Zakat (Alms) Law in Modern Indonesia", Pacific Rim Law \& Policy Journal, Sep 2006,Vol 15 No 3.

-------------, Challenging Secular State: The Islamization of Law in Modern Indonesia (Honolulu:University of Hawaii Press,2008).

Santoso,Topo, "Implementation of Islamic Criminal Law in Indonesia: Tanzor Punishment as a Solution?", IIUM Law Journal, Vol. 19 ,No. 1, 2011.

Scharbordt,Oliver, \& Mark Sedgwick, "Muhammad Abduh", Bulletin of the School of Oriental and African Studies, University of London 73.2 Juni 2010.

Sembodo, Cipto, "Reintroduksi Hukum Islam dalam Wacana Kebangsaan", UNISIA, Vol.XXXI No.69 September 2008.

Shah,Niaz A,"The Use of Force under Islamic Law", The European Journal of International Law Vol.24 No.1, 2013.

Sobotková, Veronika, "The Major Trends of Islam in Contemporary Malaysia and their Influence on the Form of Islamic Family and Penal Law" ,Archive Orientalis 80.3 (2012): 389-II,590.

Stilt, Kristen, Islamic Law in Action:Authority, Regulation, and Everyday Experiences in Mamluk Egypt, Oxford University Press, 2011.

Tanuwidjaja, Sunny,"Political Islam and Islamic Parties in Indonesia: Critically Assesing the Evidence of Islam's Political Decline", Contemporary Southeast Asia, Vol. 32, No. 1, 2010. 
Turiman, Memahami Hukum Progresif Prof Satjipto Rahardjo Dalam Paradigma "Thawaf" (Sebuah Komtemplasi Bagaimana Mewujudkan Teori Hukum Yang Membumi/Grounded Theory Meng-Indonesia (Program Doktor Imu Hukum Universitas Diponogoro, 2010).

Umar, Nasaruddin," Konstitusionalisasi Hukum Islam di Indonesia", Jurisdiksi, Edisi I,Vol. I, 1996.

Warassih, Essmi, Pranata Hukum sebuah telaah Sosiologis,( PT Suryandaru Utama,2005).

Wignjosoebroto, Soetandyo, Hukum Dalam Masyarakat, Perkembangan dan Masalah, Bayu Media, April, 2008 